надання освітніх послуг;

- збільшуються перспективи працевлаштування випускників вищих навчальних закладів;

- розв'язується проблема дефіциту робітничих кадрів в умовах сучасного ринку праці;

- оволодіння кількома суміжними робітничими кваліфікаціями значною мірою допоможе випускнику адаптуватися в соціально-економічних i технологічних умовах виробництва, що постійно змінюються.

Разом $з$ тим, організація такої системи підготовки передбачає дотримання положення, пов'язаного з тим, що людина має право займати бюджетне місце тільки один раз за весь час свого навчання. Якщо студент/учень навчається у ВНЗ/ПТНЗ на бюджеті, то він уже не має права займати бюджетне місце про одержанні робітничої кваліфікації/додаткової робітничої кваліфікації. Утім бюджетник може сплачувати за своє навчання робітничої професії зі стипендії.

Використання паралельного навчання дозволить послабити проблему дефіциту висококваліфікованої робочої сили внаслідок старіння населення і недостатньої кількості молоді, сприятиме підвищенню престижності професійно-технічної освіти, надасть змогу розширити можливості професійно-технічних навчальних закладів щодо надання освітніх послуг, при цьому значно скоротити витрати на підготовку.

\title{
Література
}

1. Заюков І. В. Перспективи розвитку професійно-технічної освіти в умовах демографічної кризи України [Електронний ресурс] / I. В. Заюков. - Режим доступу до документа: http://nauka.kushnir.mk.ua/ - Заголовок 3 екрану. 2. Інститутуційний розвиток ПТНЗ: основні підходи до бізнес-планування та маркетингу: [навч.-метод. посібн.]/ Даниленко Л. І., Сергеєва Л. М., Кашевський В. В. та ін.; / за ред. Л. І. Даниленко. - Київ: ТОВ «Етіс Плюс», 2008. - 148 с. З. Лузан П. Г. Формування змісту професійного навчання кваліфікованих робітників 3 інтегрованих професій: [метод. посібн.] / П. Г. Лузан, Ю. І. Кравець, Т. В. Пятничук. - Київ : Інститут ПТО НАН України, 2012. - 136 с. 4. Офіційний сайт Інституту демографії та соціальних досліджень ім. М. В. Птухи НАН України [Електронний pecypc].- Режим доступу до документа: http/l http://www.idss.org.ua/http://nauka.kushnir.mk.ua/. - Заголовок 3 екрану. 5. Сушенцева Л. Л. Оволодіння студентами робітничими професіями у ПТНЗ: аналіз досвіду / Л. Л. Сушенцева, О. Д. Учитель. // Професійно-технічна освіта. -2013. - № 3. - С. 45.

УДК 378.147-057

Ростислав Тарасенко

\section{ДІЯЛЬНІСНИЙ КОМПОНЕНТ ІНФОРМАЦЙНОЇ КОМПЕТЕНТНОСТІ МАЙБУТНІХ ПЕРЕКЛАДАЧІВ: ЗМІСТ, ФОРМУВАННЯ, ДІАГНОСТИКА}

Тарасенко Р. О.Діяльнісний компонент інформаційної компетентності майбутніх перекладачів: зміст, формування, діагностика.

Розглянуто питання формування діяльнісного компонента інформаційної компетентності майбутніх перекладачів. Визначено групи умінь як складників діяльнісного компоненту. Окреслено шляхи їх формування. Розроблено зміст виробничої практики, спрямованої на закріплення визначених умінь. Обгрунтована доцільність діагностики рівнів 
сформованості діяльнісного компоненту інформаційної компетентності методом експертної оцінки. Представлено аналітичну картку для проведення експертного оцінювання сформованості окремих умінь i шкалу для визначення рівнів. Наведено результати педагогічного експерименту, який засвідчив ефективність розроблених заходів для формування діяльнісного компоненту інформаційної компетентності майбутніх перекладачів.

Ключові слова: групи умінь, діяльнісний компонент, рівні, експертна оцінка, перекладач.

Тарасенко Р. А. Деятельностный компонент информационной компетентности будущих переводчиков: содержание, формирование, диагностика.

Рассмотрены вопросы формирования деятельностного компонента информационной компетентности будущих переводчиков. Определены группы умений как составляющих деятельностного компонента. Намечены пути их формирования. Разработано содержание производственной практики, направленной на закрепление определенных умений. Обоснована целесообразность диагностики уровней сформированности деятельностного компонента информационной компетентности методом экспертной оценки. Представлено аналитическую карточку для проведения экспертной оценки сформированности отдельных умений и шкалу для определения уровней. Приведены результаты педагогического эксперимента, который показал эффективность разработанных мер по формированию деятельностного компонента информационной компетентности будущих переводчиков.

Ключевые слова: группы умений, деятельностный компонент, уровни, экспертная оценка, переводчик.

Tarasenko R. O. The activity component of information competence of the future translators: content, formation, diagnosis

The article deals with problems of the activity component formation of information competence of the future translators. The groups of skills as constituent elements of the activity component are defined. The ways of its formation are outlined. The content of vocational practice is developed and aimed at developing certain skills. The expediency of diagnosing levels of activity component of information competence by expert evaluation is substantiated. The analytical card for expert evaluation of several skills formation and the scale to determine levels are presented. The results of pedagogical experiment showed the effectiveness of measures developed for the formation of the activity component of information competence of the future translators.

Key words: group of skills, activity component, levels, expert evaluation, translator.

Особливість професійної діяльності перекладача на сучасному етапі пов'язана 3 обробленням значних обсягів інформації, які постійно зростають. Виконувати цю роботу без упровадження інноваційних підходів, які грунтуються на застосуванні інформаційних технологій, досить важко, а подекуди і неможливо. Сутність цих підходів передбачає зміщення акцентів 3 індивідуальної роботи на колективну, спрямованість на спільне створення і використання корпоративних напрацювань, перехід на високотехнологічний процес перекладу із застосуванням спеціалізованих комп'ютерних систем тощо. Знання, уміння й навички, необхідні для забезпечення діяльності на такому рівні, майбутні перекладачі можуть набути у процесі формування інформаційної компетентності.

Meта статmi- розглянути змістове наповнення, процес формування і методику діагностування сформованості діяльнісного компоненту інформаційної компетентності 
майбутніх перекладачів.

Вивченням теорії діяльності, обгрунтуванням структури діяльності та ії компонентів займалися Л. Виготський, П. Гальперін, В. Давидов, Д. Ельконін, Г. Костюк, О. Леонтьєв, А. Петровський, С. Рубінштейн та ін.

Операційно-діяльнісний компонент у структурі компетентності фахівців різних галузей виокремлювали О. Діденко, А. Чудик, а діяльнісний - Н. Волкова, В. Гриньова, С. Кожушко. Проте зміст та особливості формування діяльнісного компонента інформаційної компетентності майбутніх перекладачів не були предметом окремого дослідження.

Підготовка майбутніх перекладачів передбачає їхню здатність виконувати професійну діяльність на рівні сучасних вимог, тому процес формування інформаційної компетентності має реалізовуватися через практичний складник змісту підготовки зазначених фахівців. Це, на нашу думку, означає, що формування інформаційної компетентності майбутніх перекладачів у навчальному процесі має грунтуватись на застосуванні діяльнісного підходу, згідно з яким діяльність визначають як основу, засіб і вирішальну умову розвитку особистості як форму активної цілеспрямованої взаємодії людини 3 навколишнім світом. Особистість розглядається як суб'єкт діяльності, яка сама формується в діяльності і визначає iii характер. Ураховуючи визначення С. Рубінштейном [2] діяльності як специфічної форми ставлення людини до навколишнього світу і самої себе, що виражається в доцільному перетворенні світу й людської свідомості, та тлумачення К. Абульхановою-Славською діяльності як невід'ємної передумови розвитку особистості [1], уважаємо, що тільки за умови залучення студента до різноманітних видів діяльності, пов'язані з формуванням інформаційної компетентності, тобто його власної активної участі в цій діяльності, зазначений процес може бути ефективним. Тому діяльнісний підхід при формуванні інформаційної компетентності майбутніх перекладачів передбачає визначення, включення до навчального процесу та оволодіння студентами під час практик тими видами діяльності, які формують їхню готовність та здатність до виконання професійних задач. Отже, педагогічний експеримент передбачав формування не тільки мотиваційного, когнітивного, особистісного, а й діяльнісного компонентів інформаційної компетентності.

Практична підготовка студентів під час проходження навчальних та виробничих практик переважно підсумовує та закріплює набуті знання й уміння і $є$ обов'язковим компонентом освітньо-професійної програми та змісту освіти. Вона передбачає неперервність і послідовність їі проведення з наближенням завдань, які визначені у програмі, до реалій професійної діяльності, що в нашому дослідженні стосується сучасних умов роботи перекладача з високим ступенем застосування інформаційних технологій.

Студенти експериментальної групи, які були задіяні в педагогічному експерименті, протягом місяця проходили виробничу перекладацьку практику в бюро перекладів, які спеціалізуються, в тому числі, й на перекладі текстів і документів аграрної тематики. Ці бюро були вибрані нами саме тому, що особливістю їх діяльності є організація виконання замовлень $з$ письмового перекладу переважно з використанням САТ-систем. Це означає принципово інший підхід до процесу перекладу, який набув статусу виконання перекладацьких проектів. Характерною ознакою такого підходу є спільна робота команди професіоналів, де кожен виконує свою функцію на певному етапі. Зокрема, окрім перекладачів, у процесі задіяні редактори, фахівці контролю якості перекладів, верстальники. Кожний проект у цих бюро контролюється менеджером проекту і передбачає певний набір, послідовність та терміни виконання таких операцій: переклад матеріалів перекладачем 
(фахівцем у відповідній галузі); редагування перекладеного матеріалу редактором; верстка і форматування перекладеного матеріалу; кінцева перевірка перекладеного матеріалу у відділі контролю якості.

Оскільки вся програма формувального експерименту, розроблена нами, і особливо авторський спецкурс «Інформаційні технології в перекладацькій діяльності» були зорієнтовані на здобуття знань і вироблення вмінь, які б мали практичну цінність саме за такої організації перекладацької діяльності, то студенти мали змогу закріпити їх під час проходження практики в реальних умовах професійної діяльності. 3 цією метою у зміст програми практики нами було закладено виконання завдань, які дозволили відпрацювати функції учасника перекладацького проекту на всіх етапах його реалізації. Ці завдання передбачали продовження формування визначених нами семи груп умінь, які є складниками інформаційної компетентності перекладача. Конкретизація цих груп наведена у таблиці 1.

Програма практики передбачала:

- виконання письмового перекладу текстів різних галузей 3 іноземної мови на українську та обсягом не менше 7-8 тисяч знаків за робочий день, а української на іноземну не менше 4-5 тисяч знаків;

- виконання перекладу матеріалів у форматах .doc, .xls, .ppt, .pdf різної складності 3 іноземної мови на українську та навпаки з використанням CAT-системи SDL Trados;

- здійснення пошуку і використання термінологічних online-словників в мережі Інтернет;

- здійснення пошуку довідкових матеріалів за специфікою галузі, в якій буде здійснюватися переклад матеріалів;

- робота з галузевою термінологією та формування електронного глосарію за певною галуззю аграрного спрямування обсягом не менше 150 термінів 3 дефініціями, використовуючи MS Excel;

- створення термінологічної бази засобами SDL MultiTerm, яка буде використана під час перекладу текстів відповідної тематики із застосуванням SDL Trados Studio;

- проведення у разі необхідності попередньої підготовки текстів на іноземній i українській мові для здійснення їх вирівнювання та подальшого додавання до бази пам'яті перекладів;

- здійснення аналізу оригіналу і його перекладу з точки зору лексичної, граматичної, синтаксичної, прагматичної адекватності з метою контролю якості перекладених матеріалів.

На основі набутих у процесі формування інформаційної компетентності умінь i навичок, завершальний етап якого відбувся під час проходження виробничої практики, ми діагностували сформованість діяльнісного компоненту.

Для діагностування рівня сформованості у студентів діяльнісного компоненту інформаційної компетентності через визначені нами групи умінь (інформаційно-пошукова, інформаційно-технологічна, інформаційно-технічна, інформаційно-аналітична, інформаційно-редакційна, інформаційно-тематична, інформаційно-правова), було застосовано метод експертних оцінок, пов'язаний із залученням до оцінки об'єктів і явищ, що вивчаються, найбільш компетентних людей у визначеній галузі. Під час застосування зазначеного методу дослідження необхідно виконати низку дій та операцій, які на підготовчому етапі передбачають розроблення критеріїв оцінки, визначення експертів, проведення 3 експертами відповідного інструктування. Наступним етапом $є$ здійснення експертами оцінювання об'єкта дослідження, проведення статистичної і математичної 
обробки результатів експертної оцінки, інтерпретування отриманих результатів відповідно до мети оцінювання.

До складу експертної групи були запрошені керівники та співробітники перекладацьких бюро (7 осіб), на базі яких відбувалося проходження студентами навчальної (ознайомлювальної) і виробничої перекладацької практик. Експерти, які були включені до складу експертної групи обиралися за такими критеріями: 1) стаж роботи перекладачем не менше 5 років; 2) досвід здійснення перекладацької діяльності із застосуванням інформаційних технологій, зокрема, спеціалізованого програмного забезпечення (впродовж мінімум 3 років); 3) особиста участь у реалізації перекладацьких проектів (як мінімум протягом 2 років); 4) участь у якості референта у проведенні семінарів і майстер-класів 3 підвищення кваліфікації перекладачів щодо застосування САТ-систем.

Діагностика рівня сформованості зазначених умінь здійснювалася на основі оцінок експертів, отриманих у процесі спостереження за студентами, заповнення аналітичних карт.

У результаті спостереження за діяльністю студентів під час практики, зазначені уміння оцінювалися експертами за 6-бальною шкалою $(0,1,2,3,4,5)$. Якщо експерт виставляв студенту 5 балів, це було свідченням постійного прояву визначених показників; 4 бали віддзеркалювали ситуацію, коли показники виявлялися майже постійно, за винятком окремих випадків; 3 бали означали частоту проявів показників не менше, ніж у половині випадків; 2 бали свідчили про ситуативність прояву показників; 1 бал вказував на переважну відсутність виявлення показників; 0 балів вказував на повну відсутність виявлення показників.

Під час проведення оцінювання рівня розвитку груп умінь діяльнісного компоненту проводилося заповнення аналітичної карти відповідно до визначеної шкали. При цьому за кожним показником визначалася загальна сума балів, виставлених кожним експертом зі складу комісії, та їх середнє значення. Загальний рівень діяльнісного компонента інформаційної компетентності майбутніх перекладачів визначався відповідно до суми середніх значень балів за кожним показником, які згруповані в межах вище зазначених семи груп умінь. 3 урахуванням того, що аналітична карта містила 23 показники, а кожний показник оцінювався від 0 до 5 балів, то максимальна сума середніх значень могла становити 115 балів, а мінімальна - 23. При цьому, якщо сума складала 95 - 115 балів, це свідчило про високий (продуктивний) рівень прояву умінь. У разі отримання студентом суми балів в діапазоні $74-94$ це означало досягнення ним достатнього (конструктивного) рівня. Знаходження числового значення в межах 53 - 73 бали було підтвердженням середнього (технологізованого) рівня. Якщо сума дорівнювала 52 балам або була нижчою, це було свідченням низького (репродуктивного) рівня сформованості досліджуваних умінь.

Таблиия 1.

Аналітична карта сформованості діяльнісного компонента студента М

\begin{tabular}{|c|c|c|c|c|c|c|c|c|c|}
\hline \multirow{2}{*}{ Показники (група умінь) } & \multicolumn{7}{|c|}{ Експерти } & \multirow{2}{*}{ 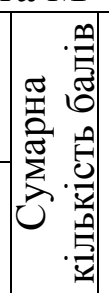 } & \multirow{2}{*}{ 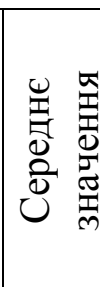 } \\
\hline & I & II & III & IV & $\mathrm{V}$ & VI & VII & & \\
\hline 1 & 2 & 3 & 4 & 5 & 6 & 7 & 8 & 9 & 10 \\
\hline Інформаційно-пошукова & & & & & & & & & \\
\hline $\begin{array}{llc}\text { Уміння } & \text { здійснювати } \\
\text { словників у мережі Інтернет } & \text { термінологічних } \\
\end{array}$ & 4 & 4 & 3 & 3 & 4 & 3 & 4 & 25 & 3,57 \\
\hline
\end{tabular}


Уміння здійснювати пошук інформаційних матеріалів для перекладу у певній галузі

\section{Інформаційно-технологічна}

Уміння використовувати системи on-line перекладу

Уміння застосовувати САТ-системи

Уміння створювати, наповнювати використовувати бази пам'яті перекладів

Уміння реалізувати перекладацькі проекти із застосуванням інформаційних технологій

\section{Інформаційно-технічна}

Уміння створювати файли 3 інформацією у різних форматах і конвертувати їх у інші формати

Уміння здійснювати обмін файлами засобами комп'ютерних мереж

Уміння здійснювати операції збереження файлів на внутрішні, зовнішні та мережеві носії інформації

Уміння встановлювати програмні продукти на ПК для перекладу

\section{Інформаційно-аналітична}

Уміння визначати потреби і враховувати вимоги замовника щодо форми та умов представлення, збереження і передачі результатів перекладу

Уміння визначати необхідні ресурси для здійснення перекладу (інформаційні, технічні, часові)

Уміння розробляти власні стратегії використання інформаційних ресурсів під час здійснення перекладу

\begin{tabular}{|c|c|c|c|c|c|c|c|c|c|}
\hline \multirow{2}{*}{\multicolumn{10}{|c|}{ Інформаційно-редакційна }} \\
\hline & & & & & & & & & \\
\hline $\begin{array}{l}\text { Уміння здійснювати редакційну підготовку тексту } \\
\text { для машинного перекладу }\end{array}$ & 3 & 4 & 4 & 4 & 3 & 3 & 4 & 25 & 3,57 \\
\hline $\begin{array}{lllll}\text { Уміння } & \text { редагувати } & \text { результати } & \text { перекладу } & 3 \\
\text { використанням програмного забезпечення } & \\
\end{array}$ & 3 & 3 & 4 & 3 & 3 & 3 & 3 & 22 & 3,14 \\
\hline Уміння вирівнювати тексти для САТ-систем & 4 & 4 & 5 & 3 & 4 & 4 & 4 & 28 & 4,00 \\
\hline \multicolumn{10}{|l|}{ Інформаційно-тематична } \\
\hline $\begin{array}{l}\text { Уміння } \\
\text { галузевих матистовувати }\end{array}$ & 3 & 4 & 3 & 3 & 4 & 4 & 3 & 24 & 3,43 \\
\hline $\begin{array}{l}\text { Уміння формувати власні електронні глосарії } 3 \\
\text { використанням офісних пакетів }\end{array}$ & 4 & 4 & 4 & 3 & 4 & 4 & 5 & 28 & 4,00 \\
\hline $\begin{array}{l}\text { Уміння формувати власні термінологічні бази } 3 \\
\text { використанням пакетів, сумісних з САТ-системами }\end{array}$ & 3 & 3 & 4 & 3 & 3 & 3 & 3 & 22 & 3,14 \\
\hline \multicolumn{10}{|l|}{ Інформаційно-правова } \\
\hline $\begin{array}{l}\text { Уміння визначати вимоги вітчизняних і зарубіжних } \\
\text { стандартів забезпечення якості перекладів }\end{array}$ & 3 & 3 & 4 & 4 & 3 & 4 & 3 & 24 & 3,43 \\
\hline $\begin{array}{lcccc}\text { Уміння дотримуватися } & \text { етичних } & \text { вимог } & \text { до } \\
\text { перекладацької діяльності } & & & \end{array}$ & 4 & 4 & 4 & 3 & 3 & 3 & 3 & 24 & 3,43 \\
\hline
\end{tabular}


Уміння використовувати інформаційні ресурси мережі Інтернет 3 дотриманням правових аспектів Уміння використовувати програмні продукти для перекладу з дотриманням ліцензійних умов

\begin{tabular}{|c|c|c|c|c|c|c|c|c|}
\hline & & & ксп & јти & & & 콣 & 氖 牙 \\
\hline I & II & III & IV & V & VI & VII & $\begin{array}{ll}0 \\
0\end{array}$ & $\circlearrowright$ \\
\hline 3 & 3 & 4 & 4 & 3 & 5 & 3 & 25 & 3,57 \\
\hline 4 & 3 & 4 & 4 & 3 & 4 & 4 & 26 & 3,71 \\
\hline & & & & & & & & 82,7 \\
\hline
\end{tabular}

Здійснений наприкінці експерименту аналіз на основі контрольного зрізу показав наявність суттєвих змін в експериментальній групі (див. табл. 2).

Таблиия 2.

\section{Динаміка рівнів сформованості діяльнісного компонента інформаційної} компетентності

\begin{tabular}{|l|c|c|c|c|}
\hline \multirow{2}{*}{ Рівні } & \multicolumn{2}{|c|}{ Контрольна група } & \multicolumn{2}{|c|}{ Експериментальна група } \\
\cline { 2 - 5 } & $\begin{array}{c}\text { На початку } \\
\text { експерименту, } \\
\text { \% }\end{array}$ & $\begin{array}{c}\text { Наприкінці } \\
\text { експерименту, } \\
\text { \% }\end{array}$ & $\begin{array}{c}\text { На початку } \\
\text { експерименту, } \\
\text { \% }\end{array}$ & $\begin{array}{c}\text { Наприкінці } \\
\text { експерименту, } \\
\text { \% }\end{array}$ \\
\hline Низький & 68,1 & 59,6 & 69,6 & 15,2 \\
\hline Середній & 31,9 & 38,3 & 30,4 & 43,5 \\
\hline Достатній & 0,0 & 2,1 & 0,0 & 34,8 \\
\hline Високий & 0,0 & 0,0 & 0,0 & 6,5 \\
\hline
\end{tabular}

Зокрема, кількість студентів, які на початку експерименту мали низький рівень сформованості діяльнісного компонента інформаційної компетентності, зменшилась із 69,6 \% до 15,2 \%. При цьому позитивна динаміка спостерігається також і на середньому рівні, де приріст склав 13,0\%. Про ефективність програми формувального експерименту свідчить те, що 34,8 \% студентів досягли достатнього рівня, а 6,5 \% високого рівня, хоч на початку експерименту студентів 3 такими рівнями сформованості діяльнісного компонента інформаційної компетентності взагалі не було.

Важливо відмітити, що досягнення студентами достатнього i високого рівня діяльнісного компонента, крім підвищення загального рівня володіння інформаційними технологіями, відбулося переважно за рахунок формування і розвитку умінь з використання систем автоматизованого перекладу, які на початку експерименту були на нульовому рівні.

У контрольній групі відбулися зрушення, які не були суттєвими, але все-таки більшими, ніж очікувано (зменшення кількості студентів 3 низьким рівнем на 8,5\%, збільшення із середнім рівнем на $6,4 \%$, збільшення із достатнім рівнем на 2,1\%), що викликало у нас запитання про причини змін. Тому ми провели опитування студентів контрольної групи. 3'ясувалося, що 4 студенти, які покращили свої показники, досягнувши середнього рівня, здійснили це за рахунок набуття умінь із використання інформаційних технологій, пов'язаних не з САТ-системами, а 3 пошуком інформації в мережі Інтернет. Окрім того, 1 студент перейшов із середнього рівня на достатній. У результаті бесіди виявилося, що цей студент під час практики у бюро перекладів мав змогу спостерігати застосування САТ-систем у процесі здійснення перекладу, про які раніше мав тільки загальну інформацію. Зацікавившись, він звернувся до керівника практики від бюро 
перекладів і з його допомогою зумів набути вмінь щодо створення термінологічних баз, які використовуються у САТ-системах. Тобто, всі зміни у контрольній групі відбулися не за рахунок спрямованості змісту навчального процесу на системне формування інформаційної компетентності майбутніх перекладачів, а шляхом їх прагнення до самовдосконалення та самостійного набуття окремих умінь щодо застосування комп'ютера для допоміжних операцій у процесі перекладу.

Отже, в результаті проведеного дослідження підтверджено ефективність розроблених заходів для формування діяльнісного компоненту інформаційної компетентності майбутніх перекладачів. Такими заходами зокрема були: уведення нових тем і модулів до змісту окремих дисциплін навчального плану та авторського спецкурсу «Інформаційні технології в перекладацьких проектах», зорієнтованих на міжнародні стандарти формування інформаційної компетентності й вимоги роботодавців щодо рівня володіння інформаційними технологіями. Експертна оцінка, яка проводилася під час проходження студентами практики у бюро перекладів, для діагностики його сформованості, дозволила виявити позитивну динаміку в експериментальній групі.

Перспективи подальшого дослідження можуть бути пов'язані із узгодженням i розширенням переліку умінь з використання інформаційних технологій у перекладацькій діяльності, які мають бути сформовані у майбутнього перекладача, на основі моніторингу вимог ринку праці та розвитку засобів і технологій у сфері перекладу.

\section{Література}

1. Абульханова-Славская К. А. Стратегия жизни / К. А. Абульханова-Славская. Москва : Мысль, 1991. - 299 с. 2. Рубинштейн С. Л. Бытие и сознание. Человек и мир / С. Л. Рубинштейн. - Санкт-Петербург : Питер, 2003. - 512 с.

\section{ІНТЕРАКТИВНІ ТЕХНОЛОГІЇ ЯК ЗАСІБ ФОРМУВАННЯ МАТЕМАТИЧНОЇ КОМПЕТЕНТНОСТІ ГАЗОЗВАРНИКІВ}

Тінькова Д. С. Інтерактивні технології як засіб формування математичної компетентності газозварників.

У статті проаналізовані деякі теоретичні аспекти інтерактивних технологій та математичної компетентності газозварників. Розглянуто використання в навчальному процесі інтерактивних методів навчання як один із важливих засобів формування математичної компетентності газозварника.

Ключові слова: математична компетентність, інтерактивні технології, газозварник.

Тинькова Д. С. Интерактивные технологии как средство формирования математической компетентности газосварщиков.

В статье проанализированы некоторые теоретические аспекты интерактивных технологий математической компетентности газосварщиков. Рассмотрено использование в учебном процессе интерактивных методов обучения, как один из важных средств формирования математической компетентности газосварщика.

Ключевые слова: математическая компетентность, интерактивные технологии, газосварщик. 